\title{
Antibacterial potency of simple fractions of ethyl acetate extract of Begonia baliensis
}

\author{
HARTUTININGSIH-M. SIREGAR ${ }^{1, \boldsymbol{\nu}}$, R.S. PURWANTORO ${ }^{1}$, PRAPTIWI $^{2}$, A. AGUSTA ${ }^{2}$ \\ ${ }^{1}$ Center for Plant Conservation-Bogor Botanic Gardens, Indonesian Institute of Sciences. Jl. Ir. H. Juanda No. 13, Bogor 16122, West Java, Indonesia. \\ Tel./fax.: +62-251-8322187. "email: hartutiningsih@yahoo.co.id \\ ${ }^{2}$ Laboratory of Natural Products, Research Center for Biology-Indonesian Institute of Sciences. Jl. Raya Jakarta-Bogor Km. 46, Cibinong 16911, West \\ Java, Indonesia
}

Manuscript received: 28 June 2018. Revision accepted: 9 August 2018.

\begin{abstract}
Siregar HM, Purwantoro RS, Praptiwi, Agusta A. 2018. Antibacterial potency of simple fractions of ethyl acetate extract of Begonia baliensis. Nusantara Bioscience 10: 159-163. Balinese people utilized Begonia baliensis Girm. (Begoniaceae) as traditional medicine to relieve cough. It was applied in a unique way by inserting the plant material into a bamboo column and then burning it in the fire. The liquid produced by the combustion process was used as a cough medicine. Based on this traditional knowledge, it is expected that $B$. Baliensis has antibacterial activity. B. baliensis plant collected from Bukit Sangyang, Penebel, Tabanan-Bali has been used in this study. The chemical compounds of ethyl acetate extracts were isolated/ separated by column chromatography. The obtained fractions were analyzed for antibacterial activity by disc diffusion assay against Escherichia coli, Bacillus subtilis, Staphylococcus epidermidis and Staphylococcus aureus. Chromatographic column yielded 14 simple fractions, whereas antibacterial test results showed 5 active fractions. Fraction 3 (F3) was active against S. epidermidis, fraction 5 (F5) against E. coli and S. epidermidis, while fractions 10, 11 and 12 were active only against Bacillus subtilis. Isolation and purification of the active components likely increased their potential as antibacterials.
\end{abstract}

Keywords: Antibacterial, Begonia baliensis, disc diffusion, simple fractions

\section{INTRODUCTION}

Herbs have been used as traditional medicine for generations by communities and are still in use. Bioactive compounds present in the plant can be detected with pharmacological approach. The study of medicinal plants as a source of pharmacologically active compounds has increased worldwide (Surasak 2009). According to Ali et al (2011) development of resistance in human pathogens against conventional antibiotic necessitates searching for indigenous medicinal plants having antibacterial property, medicinal plants used actively in folklore, ayurvedic and traditional system of medicine in Pakistan. Escherichia coli, Bacillus subtilis, Staphylococcus epidermidis and Staphylococcus aureus are amongst strong pathogen of their genera. They frequently show resistance to various medicines leading to complication in determining suitable anti-microbial selection for therapy. Treatment for infectious disease caused by antibiotic-resistant bacteria requires research for new potential cures. Study on antibacterial substance is needed to find new antibiotic to inhibit and terminate growth of antibiotic-resistant bacteria. The infectious disease still ranked the highest for cause of illness and death in developing countries, including Indonesia. Infectious disease results in physical suffering and decrease in working performance and productivity, which in the end leads to proliferation of loss. For the State, the level of infectious disease in community will lead to decrease of national productivity in general, and on the other hand, government also needs to spend more for medication expenses (Khunaifi 2010; Purwantoro et al. 2010).

In order to combat bacterial infections, antibiotics play an important role in eliminating infection-causing bacteria. However, antibiotic itself can barely cope with bacterial infections due to poor selection of antibacterial, and the emergence of resistance issues. Therefore, alternative medicines from plant resources need to be found.

Many species that belong to Begoniaceae are commonly known as ornamental plants. However, some species have been used as vegetables and medicinal herbs. Begonia glabra is used to heal a fresh wound, while $B$. fimbristipula reduces heat or fever, used as cough medicine, pain reliever and processed into fresh beverage as bitter tea (Tebbit 2005). B. grandis is used as a herbal medicine to clean wounds, to reduce swelling and to treat a number of diseases. B. lailana B. baramensis, B. stenogyna and $B$. lazat are used as vegetables in Kuching (Kiew et al. 2015). In West Java, Indonesia, B. multangula and $B$. robusta are used as tamarind substitutes in cooking because of their sour taste.

In Balinese society, Begonia baliensis with local name Bacem Kebo has been used as a traditional medicine and vegetable. Bacem kebo identified as B.baliensis is a new Begonia species endemic to Bali (Girmansyah 2008). This species grows with only a limited population size on the slopes of Bukit Tapak, Candikuning, Tabanan, Bali. (Satyanti et al 2013). Continuous harvest from its natural habitat will cause declining wild population. Sustainable 
harvest management supported by intensive cultivation will help to maintain natural population.

Raw young leaves and stems are traditionally eaten as vegetables. This plant is also considered as a traditional medicine to treat cough (Siregar 2008). Stems and leaves are inserted in bamboo, then burnt on fire. The discharge is used as a cough medicine.

Previous research has shown that Begonia muricata, $B$. multangula, $B$. baliensis have antibacterial activity against Escherichia coli and Staphylococcus aureus (Purwantoro et al. 2011). Based on the previous results, this study is carried out to determine the antibacterial activity of the simple fractions of $B$. baliensis extract.

\section{MATERIALS AND METHODS}

\section{Material}

Begonia baliensis plant was collected from the forest area of Shangyang Hill, Jatiluwih, Tabanan, Bali. B.baliensis plant was cleaned and cut into small pieces, then dried under the sun. The dried samples were ground into powder.

\section{Extraction}

B. baliensis powder (207.13 grams) was extracted by maceration method using three different solvents namely, n-hexane, ethyl acetate and methanol with different polarities. Maceration in each solvent was performed 3 times, the filtrate was collected and concentrated with a rotary evaporator. The extract was weighed to know the rendement extract. Rendement extract is the weight of the extract divided by the weight of the sample multiplied by $100 \%$.

\section{Isolation of bioactive compounds}

The chemical compounds of ethyl acetate extract of $B$. baliensis ( $1 \mathrm{~g})$ were separated by column chromatography using silica gel $(300 \mathrm{~g})$ as the stationary phase. The mobile phase was a mixture of dichloromethane-methanol in a ratio of $30: 1$ to $1: 1$ and finally $100 \%$ methanol. The eluates were monitored with TLC. Eluate with similar TLC patterns combined into one as a simple fraction. The simple fraction was then tested for its antibacterial activity.

\section{Antibacterial test}

Simple fractions of ethyl acetate extract was tested for antibacterial activity against Escherichia coli, Bacillus subtilis, Staphylococcus epidermidis and Staphylococcus aureus. All isolates were cultured on Mueller Hinton Agar in petri dish. Each simple fraction was tested for antibacterial activity using the disc diffusion method. Sterile blank disc $(6.0 \mathrm{~mm}$ in diameter) were impregnated with different concentrations $(50 \mu \mathrm{g}, 100 \mu \mathrm{g}$, and $200 \mu \mathrm{g})$ of fraction. The impregnated disc was placed on Mueller Hinton Agar in petri dish that had been inoculated with the test bacteria. All antibacterial work was carried out aseptically in the laminar air flow. The petri dish was then incubated for 24 hours at $37^{\circ} \mathrm{C}$. Observation of growth inhibition by test bacteria was done after incubation was completed. The antibacterial activity was determined by measuring the diameter of clear zone of inhibition.

\section{RESULTS AND DISCUSSION}

\section{Morphological characters}

Begonia baliensis Girmansyah. Stem brownish green to reddish brown, erect and cane-like, succulent, rhizomatous, hairy, herbaceous, $15-50 \mathrm{~cm}$ tall. Stipules pale green. Leaves distant; 5-15 cm apart, petiole pale green to reddish brown, hairy, asymmetric, 14-21 x 11-18 cm, basal lobe rounded, apex acuminate; venation palmate-pinnate. Inflorescences axillary, few flowered, shorter than the leaves, protandrous, peduncle 2-8 cm long, green, glabrous; bract absent. Male flowers 4 , with a pale reddish green pedicel 1.3-2.5 cm long; tepals 4, white and red around the middle, inner two similar but smaller, milky white, 11-14 x 8-9 mm, anthers pale yellow. Female flowers 7, with a pale green pedicel 4-5 mm long; ovary dark green with reddish brown at the larger wing, thick and fleshy, 7-9 x 5-8 mm, locules 3, placentas 2 per locule; tepals 5, milky white, outer two reddish white, broadly obovate, margin not toothed. Fruit a berry, pendant on a stiff fleshy pedicel, 4-5 $\mathrm{mm}$ long, green when ripe, fleshy (Figure 1). Distribution. Bali. Habitat. Humid forest, along trails at 1300-1800m (Girmansyah 2008)

The rendement of extract was presented in Table 1 . The highest result was in methanol extract (13.04\%), followed by $n$-hexane extract $(1.67 \%)$ and ethyl acetate $(4.57 \%)$.

\section{Isolation of bioactive compounds from ethyl acetate Begonia baliensis extract}

Previous research showed that ethyl acetate extract has antibacterial activity against Bacillus subtilis and Pseudomonas aeruginosa (Siregar et al. 2014). In the present study, separation of chemical compounds of ethyl acetate extract of $B$. baliensis was done by column chromatography. Figure 2. showed that ethyl acetate extract of $B$. baliensis contained several chemical compounds indicated by several spots on TLC plate.

The chromatogram profile of simple fractions from ethyl acetate extract of $B$. baliensis (Figure 3) showed that one fraction still contained several chemical compounds indicated by the existence of several 'spots' in the fraction.

\section{Antibacterial properties of simple fraction}

All simple fractions of ethyl acetate extract were assayed for their antibacterial activity against $E$. coli, $S$. epidermidis, and B. subtilis by the paper disc diffusion method. The antibacterial test results are shown in Figure 4 and Table 1. The results of the antibacterial test show that 5 fractions have antibacterial activity, i.e., fraction (F) 3 is capable of inhibiting the growth of $S$. epidermidis, F5 is active against $E$. coli and $S$. epidermidis, whereas F10, F11, and $\mathrm{F} 12$ are active against $B$. subtilis. 


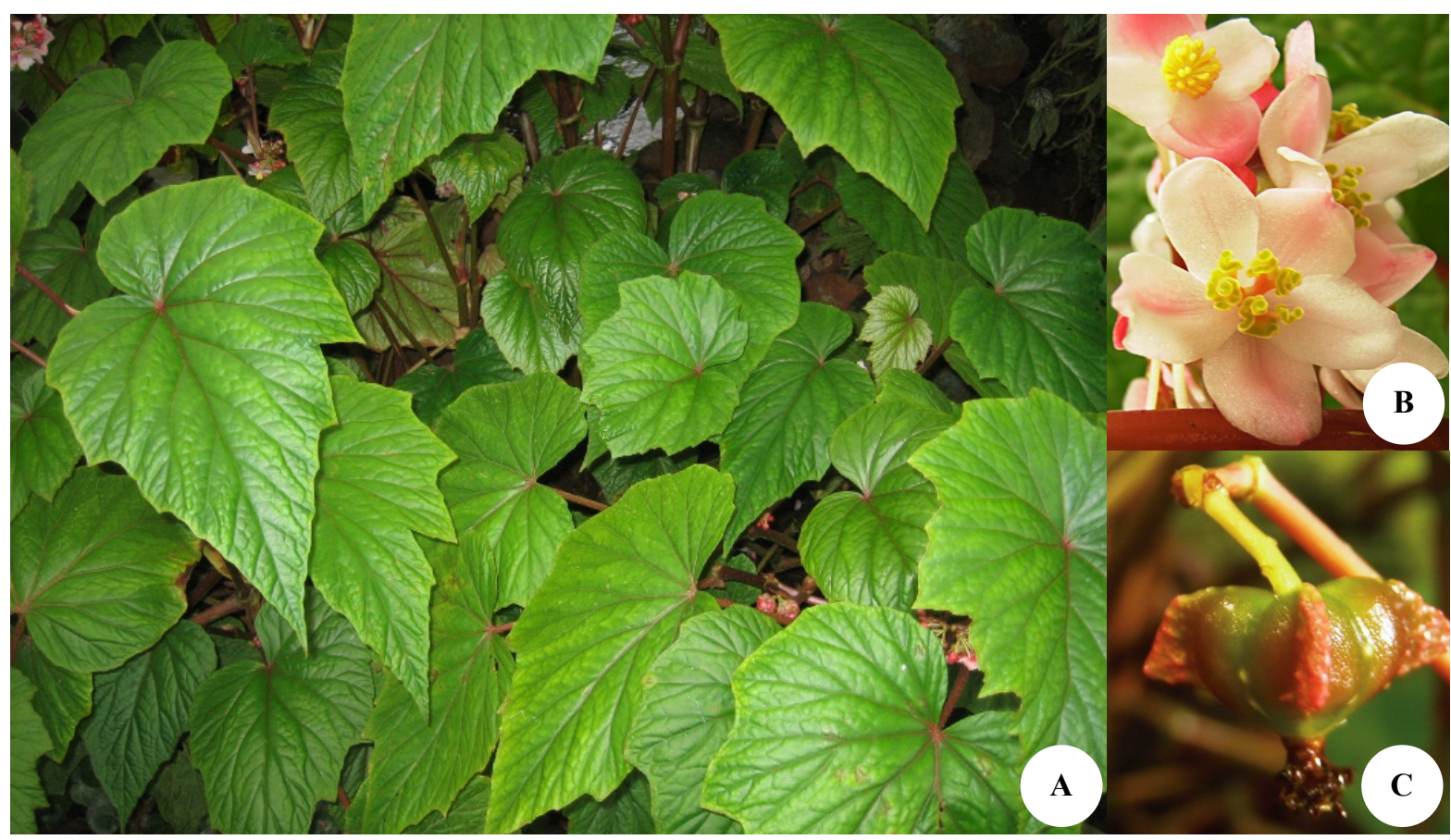

Figure 1. Morphological features of Begonia baliensis Girm. A. Leaves, B. Flowers, C. Fruit

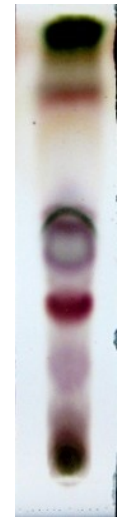

Sample : ethyl acetate extract of Begonia baliensis TLC : Merck GF254

Solvent : dichloromethane-methanol (10:1)

Stain reagent: $2 \% \mathrm{CeSO}_{4}$ in $10 \% \mathrm{H}_{2} \mathrm{SO}_{4}$

Figure 2. TLC profile of ethyl acetate extract of Begonia baliensis

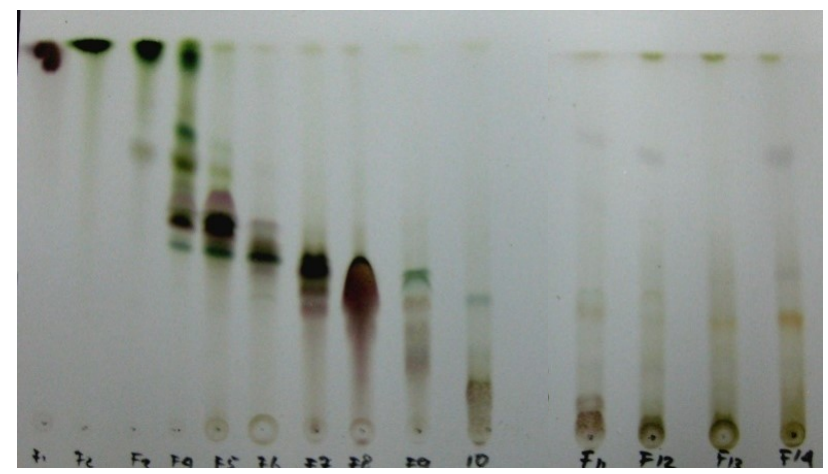

Figure 3. Chromatogram of simple fractions of ethyl acetate extract Begonia baliensis. Mobile phase: Dichloromethane: methanol (10:1). Stain reagent: Cerium sulfate

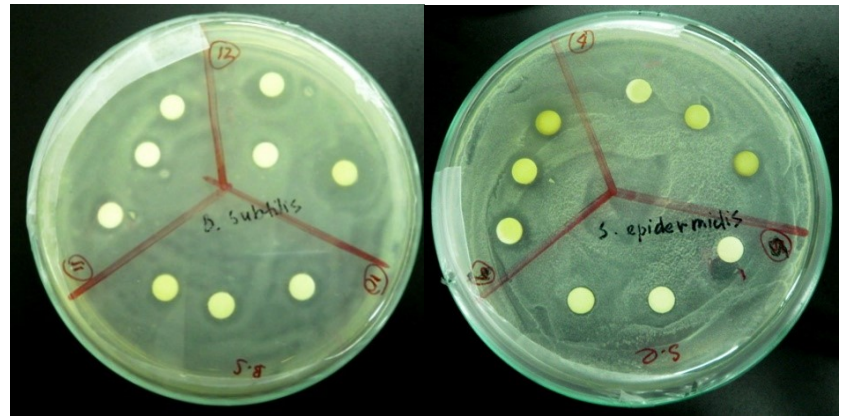

Figure 4. Inhibitory zone of simple fractions of ethyl acetate Begonia baliensis extract against Bacillus subtilis and Staphylococcus epidermidis by the paper disc diffusion. The clear zone indicated bacterial growth inhibition.

Table 1. Weight of Begonia baliensis leaf extract

\begin{tabular}{lcc}
\hline Extract & $\begin{array}{c}\text { Weight extract (g) } \\
\text { B. baliensis }\end{array}$ & Rendement (\%) \\
\hline n-hexane & 3.46 & 1.67 \\
Ethyl acetate & 9.46 & 4.57 \\
Methanol & 27 & 13.04 \\
\hline
\end{tabular}

Extraction of $B$. baliensis was carried out using different solvents with different polarity, i.e., hexane, ethyl acetate, and methanol. According to Sani et al. (2014), the solvent plays an important role in producing a high yield of extract. The chemical compounds will be extracted in a solvent with the same polarity. The result showed that the 
highest percentage of extract or rendement was methanol extract. This is because almost all chemical compounds can be dissolved in methanol. According to Marcus and Glikberg (1986), methanol is a good solvent for polar organic substances. The highest percentage of methanol extract indicated the relatively high content of polar chemical compounds (Yuhernita and Yuniarti 2011).

The chemical compound in ethyl acetate extracts was separated by thin layer chromatography (TLC). According to Sashidaran et al. (2011), the TLC is a simple, inexpensive and quick method to determine the chemical compounds in the extract.

In the earlier research, it was found that the ethyl acetate extract of $B$. baliensis was able to inhibit the growth of Bacillus subtilis and Pseudomonas aeruginosa. This indicated that the ethyl acetate extract contains chemical compounds having antibacterial activity. According to Suresh et al. (2016), the Indian medicinal plants tested, Acalypha indica and A. lanata showed a significant antibacterial activity. A. indica showed potential activity against Staphylococcus aureus and E. coli. A. lanata significantly exhibited antibacterial activity against $E$. coli, Salmonella typhi, and Pseudomonas aeruginosa.

The fractionation with chromatography column yielded 14 simple fractions. Several fractions have antibacterial activity, i.e., F3, F5, F10, F11, and F12. The growth of $E$. coli was only inhibited by F5 at the concentration of 200 ug. The antibacterial assay showed that Gram-negative $(E$. coli) bacteria were less sensitive than gram-positive bacteria (B. subtilis, S. epidermidis and $S$. aureus) to simple fractions of Begonia baliensis. According to Kusmiyati and
Agustini (2007), Gram-positive bacteria have a simpler cell wall so that it might be more sensitive to antibacterial compounds. Gram-negative bacteria have more complex cell walls with layer of lipoproteins on the outside of their cell walls (Chan et al. 2005). Therefore Gram harmful bacteria become less sensitive to antibacterial compounds.

The result (Table 2) showed the tendency of increasing inhibition of bacterial growth by increasing fraction concentration. This is because the increase in concentration of the extract increased the concentration of antibacterial compounds. According to Zuhud et al. (2001), the higher concentration of extract and the duration of contact resulted in the easier penetration of antibacterial compounds through the bacterial cell wall.

In conclusion, Begonia baliensis contains many polar compounds, in which the yield of methanol extract is the highest one (13.04\%). However, the active extract is ethyl acetate extract. Five simple fractions of ethyl acetate extracts namely, F3, F5, F10, F11, and F12 showed the antibacterial activities, and only F5 was active against Escherichia coli. Fraction three (F3) was active against Staphylococcus epidermidis, F5 was active against Escherichia coli and Staphylococcus epidermidis, while F10, F11, and F12 are selectively active against Bacillus subtilis. Isolation and purification of the active compounds might improve their potency as antibacterials. A simple fraction of ethyl acetate of $B$. baliensis extract which has antibacterial activity needs to be further analyzed for the isolation and characterization of potentially antibacterial chemical components.

Table 2. Weight of simple fraction of ethyl acetate Begonia baliensis extract and its inhibitory zone

\begin{tabular}{|c|c|c|c|c|c|c|c|c|c|c|c|c|c|}
\hline \multirow{3}{*}{$\begin{array}{l}\text { No. } \\
\text { fraction }\end{array}$} & \multirow{3}{*}{$\begin{array}{c}\text { Weight } \\
\text { (mg) }\end{array}$} & \multicolumn{12}{|c|}{ Inhibitory zone (mm) against } \\
\hline & & \multicolumn{3}{|c|}{ E.coli } & \multicolumn{3}{|c|}{ B.subtilis } & \multicolumn{3}{|c|}{ S.epidermidis } & \multicolumn{3}{|c|}{ S.aureus } \\
\hline & & $\begin{array}{l}50 \\
\mu \mathrm{g}\end{array}$ & $\begin{array}{c}100 \\
\mu \mathrm{g}\end{array}$ & $\begin{array}{l}200 \\
\mu \mathrm{g}\end{array}$ & $\begin{array}{l}50 \\
\mu \mathrm{g}\end{array}$ & $\begin{array}{l}100 \\
\mu \mathrm{g}\end{array}$ & $\begin{array}{l}200 \\
\mu \mathrm{g}\end{array}$ & $\begin{array}{l}50 \\
\mu \mathrm{g}\end{array}$ & $\begin{array}{c}100 \\
\mu \mathrm{g}\end{array}$ & $\begin{array}{c}200 \\
\mu \mathrm{g}\end{array}$ & $\begin{array}{l}50 \\
\mu \mathrm{g}\end{array}$ & $\begin{array}{l}100 \\
\mu \mathrm{g}\end{array}$ & $\begin{array}{c}200 \\
\mu \mathrm{g}\end{array}$ \\
\hline 1 & 24.60 & - & - & - & - & - & - & - & - & - & - & - & - \\
\hline 2 & 29.30 & - & - & - & - & - & - & - & - & - & - & - & - \\
\hline 3 & 46.00 & - & - & - & - & - & - & - & - & 8 & - & - & - \\
\hline 4 & 96.70 & - & - & - & - & - & - & - & - & - & - & - & - \\
\hline 5 & 21.90 & - & - & 7 & - & - & - & - & 8 & 9 & - & - & - \\
\hline 6 & 7.80 & - & - & - & - & - & - & - & - & - & - & - & - \\
\hline 7 & 23.20 & - & - & - & - & - & - & - & - & - & - & - & - \\
\hline 8 & 41.40 & - & - & - & - & - & - & - & - & - & - & - & - \\
\hline 9 & 49.50 & - & - & - & - & - & - & - & - & - & - & - & - \\
\hline 10 & 22.60 & - & - & - & - & 8 & 8 & - & - & - & - & - & - \\
\hline 11 & 98.70 & - & - & - & 7 & 7 & 8 & - & - & - & - & - & - \\
\hline 12 & 23.00 & - & - & - & - & 9 & 11 & - & - & - & - & - & - \\
\hline 13 & 9.90 & - & - & - & - & - & - & - & - & - & - & - & - \\
\hline 14 & 16.2 & - & - & - & - & - & - & - & - & - & - & - & - \\
\hline Acetone & & & & - & & & - & & & - & & & - \\
\hline Methanol & & & & - & & & - & & & - & & & - \\
\hline
\end{tabular}




\section{ACKNOWLEDGEMENTS}

Authors acknowledge the Head of Center for Plant Conservation-Bogor Botanic Gardens, Indonesian Institute of Sciences and DGHE, Indonesia. This work was conducted within the framework of Research Incentive Project for Researcher and Engineer, Synergy Activity of Research and Development of Science and Technology 2009-2010. Thanks to Prof. Dedy Darnaedi who helped correct the manuscript. Thanks also go to Dr. Sudarmono, Annisa Satyanti, Wihermanto, YWC Kusuma, WH Ardi and Sumanto who were willing to share their knowledge and Andi Saptaji Kamal for his help in Natural Product Laboratory, Research Center for Biology, Indonesian Institute of Sciences (LIPI), Bogor, Indonesia.

\section{REFERENCES}

Ali NH, Shaheen F, Shahana UK. 2011. Antibacterial activity in spices and local medicinal plants against clinical isolates of Karachi, Pakistan. Pharmaceut Biol 49 (8): 833-839.

Chan ECS, Pelczar JrMJ, Krieg NR. 2005. Microbiology. 5th ed. Tata McGraw-Hill Education Pvt. Ltd., New Delhi.

Girmansyah D. 2008. A taxonomic study of Bali and Lombok Begonia (Begoniaceae). Reinwardtia 12 (5): 419-434.

Jeeva S, Marimuthu J, Antonisamy. 2012. Anti-bacterial and phytochemical studies on methanolic extracts of Begonia floccifera Bedd. Flower. Asian Pac J Trop Biomed 1 (1): S151-S154

Khunaifi M. 2010. Test of antibacterial activity of binahong leaf extract (Anredera cordifolia (Ten) Steenis against Staphylococcus aureus bacteria and Pseudomonas aeruginosa. [Thesis]. Department of Biology, Faculty of Science and Technology, State Islamic University Maulana Malik Ibrahim, Malang. [Indonesian]

Kiew R, Sang J, Repin R, Ahmad JA. 2015. A Guide to Begonias of Borneo. Natural History Publications (Borneo). Sdn. Bhd., Kota Kinabalu, Sabah, Malaysia.
Kusmiyati, Agustini NWS. 2007. Activity test of antibacterial compounds from microalgae Porphyridium cruentum. Biodiversitas 8 (1): 48-53. [Indonesian]

Purwantoro RS, Hartutiningsih-M. Siregar, Sudarmono, Praptiwi. 2010. Antibacterial test Lasianthus (Rubiaceae) as a medicinal plant and its propagation efforts. Buletin Kebun Raya 13 (2): 86-93. [Indonesian]

Purwantoro RS, Siregar HM, Satyanti A, Wihermanto, Kusuma YWC, Sumanto. 2011. Characterization of active components in Begonia baliensis extract and Lasianthus obscurus (Rubiaceae) as medicinal raw materials and conservation aspects. Proposal of Researcher and Engineer Incentive Activities LIPI, Research and Technology, LIPI, Bogor.

Sasidharan S, Chen Y, Saravanan D, Sundram KM and Yoga Latha L. 2011. Extraction, isolation, and characterization of bioactive compounds from plant extracts. Afr J Tradit Complement Altern Med 8 (1): 1-10.

Satyanti A, Siregar HM. 2012. Microclimate preference and habitat of Begonia in Bedugul Bali. Biotropia 19 (2): 80-91.

Siregar HM, Purwantoro RS, Sudarmono, Fijriyanto IA, Satyanti A,Agusta A. 2014. Bio pharmacy potential of Begoniaceae (Begonia muricata Blume, B. multangu Blume, B. baliensis Girmansyah) through in vitro antibacterial test and antifungal test. Proceedings The 2nd International Symposium on Temulawak. The 40th Meeting of National Working Group on Indonesian Medicinal Plant. Institute of Research and Community Services-Bogor Agricultural University, Indonesia: 190-195.

Siregar HM. 2008.Knowing and caring Begonia. PT Agromedia Library. Jakarta. [Indonesian]

Surasak L, Sanan S, Supayang PV. 2009. Medicinal plants with significant activity against important pathogenic bacteria. Pharmaceutical Biology 47 (8): 683-689.

Suresh M, Mohammad SAA, Pradipta KR, Panneerselvam A, Thajuddin N. 2016. Screening and antibacterial efficacy of selected Indian medicinal plants. Asian Pac J Trop Biomed 6 (3): 185-191.

Tebbitt MC. 2005. Begonias. Cultivation, Identification, and Natural History. Timber Press, USA.

Yuhernita, Juniarti. 2011. Analysis of secondary metabolite compounds from leaf methanol extract surian potential as an antioxidant. Makara Sains 15 (1): 48-52.

Zuhud EAM, Rahayu WP, Wijaya CH, Sari PP. 2001. Antimicrobial activity of kedawung extract (Parkia roxburghii G. Don) to pathogenic bacteria. Jurnal Teknologi \& Industri Pangan 12 (1): 6. 